\title{
STUDIES ON HIGH STRENGTH SELF COMPACTING CONCRETE WITH COPPER SLAG FOR M30 GRADE
}

\author{
Daniel $\mathbf{C}^{\mathbf{1}}$, Joel Shelton $\mathbf{J}^{\mathbf{2}}$, Vincent Sam Jebadurai $\mathbf{S}^{\mathbf{3}}$, Arun Raj $\mathbf{E}^{\mathbf{4}}$ \\ ${ }^{I} P G$ Student, School of Civil Engineering, Karunya University, Tamilnadu, India \\ ${ }^{2}$ Research Scholar, School of Civil Engineering, Karunya University, Tamilnadu, India \\ ${ }^{3}$ Assistant Professor, School of Civil Engineering, Karunya University, Tamilnadu, India \\ ${ }^{4}$ Assistant Professor, School of Civil Engineering, Karunya University, Tamilnadu, India
}

\begin{abstract}
This research paper present an experimental investigation of the result of using copper slag (CS) asfine aggregate for replacement of river sand in self-compacting concrete (SCC).Totally Eleven concrete mix proportion are prepared with various mix ratio of copper slag varies from 0\% (for the control mix ratio) to 100\%. Test methods used to study the characteristics of fresh concrete were slump test, U-tube, V-funnel and L-box. Concrete mix are tested for workability, density, durability, compressive strength and tensile strength. The results shows there is a lessincrease in high performance concretedensity of $3 \%$ with therise of copper slag as fine aggregate, whereas the workability increase quickly with increases in CS percentage. In adding up to $40 \%$ of copper slag as fine aggregate replacement yielded comparable strength with that of the control mix. However, further additions of CS cause reduction in the high strength due to an increase of water content in the mix proportions. Mixes with 90 and 100\% copper slag replacement gave the low compressive strength values. Therefore, it is recommended 50 weight $\%$ of CS can used as replacement of sand as fine aggregate in order to acquire high performance.
\end{abstract}

Keywords: Self-Compacting Concrete, Segregation, Flyash, Copper Slag, Workability

\section{INTRODUCTION}

The construction of modern and complicated civil engineering structures have become a part of today's fast developing world. Concrete known for its high compressive strength, workability and durability plays a vital role in construction. To construct durable structures, it is necessary to improve the performance and properties of concrete. It leads to the invention of high performance concrete (HPC). Self Compacting Concrete (SCC) is a high performance concrete that has very low viscosity and high resistance to segregation, doesn't require mechanical vibration during casting. Hence SCC has been widely accepted in the construction industry.

In the recent times, construction activity has increased many times in India. Fast growth in the construction industry in our country relies on the use of a natural resources, for infrastructure development. Large-scale production of portland cement and the rapid exploitation of the environment for aggregates in the last decade, have a dramatic impact on the environment.The available of natural resources is reducing in India, slowing down the growth in construction activity. The rapid depletion of natural resources along with the substantial increase in waste generation poses a serious problem.

In day to day life, several types of byproducts and waste materials are generated through commercial / industrial activities. These waste materials need to be effectively recycled or safely disposed. The utilization of such waste materials in concrete not only makes it economical but also helps for decrease disposals. Hence appropriate technology is needed to know their use in concrete. Utilizing these waste materials for the manufacture of SCC, makes SCC economical, reduces disposal problems.

A fine example of use of waste material in concrete would be Copper slag, which can replace either cement or aggregate partially or completely. Although studies indicate use of Copper slag as aggregate influences the performance of concrete, not much research has been done regarding its use as fine aggregate in SCC. Cooper slag is a by-product in the manufacture of copper. For every ton of copper produced, roughly 3 tons of copper slag gets generated. The Tuticorin plant of Sterlite has a capacity of 400,000 ton of copper per annum and generates roughly 1.2 million ton of copper slag. This polluting material needs to be properly disposed. This waste material is used for many purposes, mostly for land filling to grid blasting.

\section{EXPERIMENTAL PROGRAM}

In the present investigation, one mixes were studied with different mix proportions of copper slag varies from $0 \%$ to $100 \%$. The water binder ratio (w/b) for both mixes was maintained at 0.4 . The dosage of the super plasticizer was maintained at $0.6 \%$ of the total powder content to maintain the desired flow characters.

\subsection{MATERIALS}

Ordinary Portland cement -53 grade, confirming to Indian Standard 1489-1991 was used for casting the specimen. Locally available river sand of having a maximum size of 
$4.75 \mathrm{~mm}$, confirming to IS: 383 - 1970 was used as fine aggregate.Crushed blue granite, $12.5 \mathrm{~mm}$ size, angular shape was used as coarse aggregate. Potable water as per IS $456-$ 2000, suitable for drinking was used for casting as well curing. A polycarboxylic either based Super plasticizer GleniumB233.

2.1.1 Cement:OPC -53 grade cement with the following properties. Fineness 7\%,Specific Gravity 3.09, Initial setting time $32 \mathrm{~min}$, Final setting time $360 \mathrm{~min}$, Compressive Strength of $44 \mathrm{MPa}$ on 7 th day, $58 \mathrm{MPa}$ on 28th day.

2.1.2 Fine Aggregate : Natural sand,Fineness Modulus 2.65 as per IS $383-197$, Specific Gravity 2.78 , Clay content $3 \%$, water absorption $1.05 \%$, Density $2.3 \mathrm{gm} / \mathrm{cc}$, Dry rodded Bulk Density 1610 kg/m3, Loose Bulk Density 1430 kg/m3

2.1.3 Coarse Aggregate : Crushed blue granite, $12.5 \mathrm{~mm}$ size, angular shape, Specific Gravity 2.61, Fineness modulus $=5.9$ as per IS 383-1978, Dry rodded bulk density $=1480$ $\mathrm{kg} / \mathrm{m} 3$, Loose bulk density $=1290 \mathrm{~kg} / \mathrm{m} 3$

2.1.4 Flyash: Specific Gravity 2.20, Passing through 75 micron sieve, fineness $290 \mathrm{~m} 2 / \mathrm{kg}$, From Neyveli Lignite Corporation, Light grey in color

2.1.5 Copper Slag: Black in color, bulk density 2.25 gm/cm3, Specific Gravity 4.27, water absorption $0.28 \%$, fineness modulus 3.17, $\mathrm{SiO} 231.40 \%$, Fe2O3 54.25\%, Al2O3 $4.30 \%$

2.1.6 Super Plasticizer: Light brown Color with Specific Gravity 1.2 , Relative Density at $25^{\circ} \mathrm{C}$ is $1.09 \pm 0.0$, Chloride iron content $<0.2 \%, \mathrm{pH}>6$.

2.1.7 Water: Potable water as per IS 456 - 2000

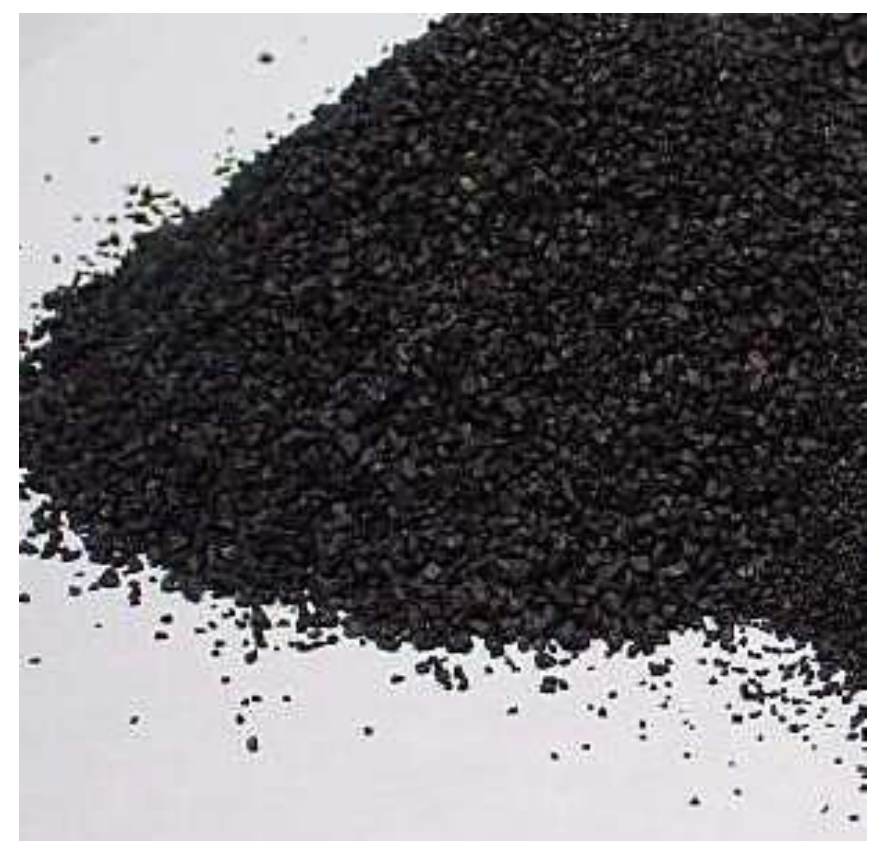

Fig -1: Copper slag used in casting

\subsection{PROPORTIONING}

The mix proportioning of SCC was obtained by changing the paste volume (i.e. powder and water content) with a constant volume of coarse aggregate and fine aggregate. SelfCompatibility can be more affected by the Material characteristics and the mix ratio. A mix proportion for selfcompacting concrete using a variousof materials is needed. The coarse aggregate and fine aggregate are fixed common so that self-compaction can be achieved easily by adjusting the water-cement ratio and superplasticizer only.

From the literature studios trial proportion of SCC mixtures were determine on the following basis. Coarse aggregate content not exceeds $50 \%$ of solid volume. Sand content on the volume basis not to exceed $40 \%$ of mortar volume. The water to powder ratio on volume basis is of 0.9 to 1.0 depending the properties of the super-plasticizer. Water content and super-plasticizer dosage to determine to make sure self- compatibility.

From the above guide lines the mix proportions are prepared and workability test is carried out. This trial mixtures are failed in $\mathrm{U}$-tube lest, because segregation is occurs in the Utube. Aggregate content 50\% of solid volume is suggested for rounded aggregate but for angular aggregate it is reduced to $46 \%$ of solid volume.

\subsection{PREPARING AND CASTING THE TEST} SPECIMEN

To prepare the concrete mix, coarse aggregate was placed inside the concrete mixer followed by fine aggregate. Then $20 \%$ of the total quantity of water was added. The concrete mixer was allowed to rotate a few times then Flyash and cement were added. Approximately $40 \%$ of the total water quantity was poured to concrete mixer and the materials were mixed for 1 minute. Superplasticizer has been added to the remaining quantity of water content and added to the mixer machine. Mixing was continued for another 2 minutes. After mixing, tests were conducted to determine the properties of the fresh concrete. They include slump, V funnel, L box, U Box and $\mathrm{J}$ ring test are done. If the mix satisfies the required SCC parameters, specimens were cast without any compaction. 
Table -1: Mix Design of SCC

\begin{tabular}{|l|l|l|l|l|l|l|l|l|l|l|l|}
\hline Component & $\mathbf{0 \%}$ & $\mathbf{1 0 \%}$ & $\mathbf{2 0 \%}$ & $\mathbf{3 0 \%}$ & $\mathbf{4 0 \%}$ & $\mathbf{5 0 \%}$ & $\mathbf{6 0 \%}$ & $\mathbf{7 0 \%}$ & $\mathbf{8 0 \%}$ & $\mathbf{9 0 \%}$ & $\mathbf{1 0 0 \%}$ \\
$\mathbf{c s}$ & $\mathbf{c s}$ & $\mathbf{c s}$ & $\mathbf{c s}$ & $\mathbf{c s}$ & $\mathbf{c s}$ & $\mathbf{c s}$ & $\mathbf{c s}$ & $\mathbf{c s}$ \\
\hline Cement(Kg) & 415 & 415 & 415 & 415 & 415 & 415 & 415 & 415 & 415 & 415 & 415 \\
\hline Fly ash (Kg) & 141 & 141 & 141 & 141 & 141 & 141 & 141 & 141 & 141 & 141 & 141 \\
\hline Sand(Kg) & 900 & 810 & 720 & 630 & 540 & 450 & 360 & 270 & 180 & 90 & 0 \\
\hline $\begin{array}{l}\text { Gravel } \\
\text { mm(Kg) }\end{array}$ & 452 & 452 & 452 & 452 & 452 & 452 & 452 & 452 & 452 & 452 & 452 \\
\hline $\begin{array}{l}\text { Gravel } \\
\text { mm(Kg) }\end{array}$ & 310 & 310 & 310 & 310 & 310 & 310 & 310 & 310 & 310 & 310 & 310 \\
\hline $\begin{array}{l}\text { Water } \\
\text { (litres) }\end{array}$ & 162 & 162 & 162 & 162 & 162 & 162 & 162 & 162 & 162 & 162 & 162 \\
\hline $\begin{array}{l}\text { Super } \\
\text { plasticizer } \\
\text { (litres) }\end{array}$ & 3.2 & 3.2 & 3.2 & 3.2 & 3.2 & 3.2 & 3.2 & 3.2 & 3.2 & 3.2 & 3.2 \\
\hline $\begin{array}{l}\text { Copper slag } \\
\text { (kg) }\end{array}$ & 0 & 90 & 180 & 270 & 360 & 450 & 540 & 630 & 720 & 810 & 900 \\
\hline
\end{tabular}

\subsection{PREPARING AND CASTING THE TEST SPECIMEN}

To prepare the concrete mix, coarse aggregate was placed inside the concrete mixer followed by fine aggregate. Then $20 \%$ of the total quantity of water was added. The concrete mixer was allowed to rotate a few times then Flyash and cement were added. Approximately $40 \%$ of the total water quantity was poured to concrete mixer and the materials were mixed for 1 minute. Superplasticizer has been added to the remaining quantity of water content and added to the mixer machine.Mixing was continued for another 2 minutes. After mixing, tests were conducted to determine the properties of the fresh concrete. They include slump, V funnel, $\mathrm{L}$ box, $\mathrm{U}$ Box and $\mathrm{J}$ ring test are done. If the mix satisfies the required SCC parameters, specimens were cast without any compaction.

\subsection{CURING THE SPECIMEN}

After casting, the specimens were given a smooth finish with a steel trowel. The specimens were stored in room temperature approximately $26^{\circ} \mathrm{C}$ for 24 hours. After hardening, the specimens mould is removed, placed in potable water for 7 and 28 days for curing. After the curing specimens were taken out and tested.

\subsection{TESTS ON FRESH CONCRETE}

slump flow test, $\mathrm{U}$ - flow test, $\mathrm{V}$ - flow time, $\mathrm{L}$ - Box test are in used to evaluate the fresh concrete properties of SSC.

\subsubsection{Slump Flow Test}

Workability of ordinary concrete is primarily governed by its water content whereas the workability of SCC is determined by the chemical and mineral admixtures used. The setting time of SCC is only slightly higher than that of regular concrete. If required, retarders and set accelerators can be used to control the setting times.

The simplest and common adopted test for evaluating selfcompatibility quality of SCC is slump flow test. This test has a measurement of mean diameter of concrete flowing out of the slump cone after the concrete had stopped flowing. Measuring of slump flow indicates the flow of SCC and determines the consistency and cohesiveness of the SCC. The SCC is characterized by a flow of 660 to $720 \mathrm{~mm}$.

\subsubsection{U - Box Test}

This test shows the behavior of concrete in the simulated conditions. The $U-$ Box test gives an indication of the resistance of mix to flow around the abstraction in a $\mathrm{U}-$ Box mould.This detects the tendency of coarse aggregate particles to settle down when the mixture flows through the closely spaced reinforcement. If the filling height is more 
than $70 \%$ of the tube, it is considered as SCC. This test is used to optimize percentage of aggregate content required in total volume of concrete.U-Box test measures filling and segregation properties of SCC.

\subsubsection{L - Box Test}

The L - Box test apparatus of having a vertical and horizontal section.Reinforcement bars are placed at the middle of two sections of the apparatus. In general, the gap between the reinforcement bars kept at 35 and $55 \mathrm{~mm}$ for $10 \mathrm{~mm}$ and $20 \mathrm{~mm}$ coarse aggregate respectively. The time taken for the concrete flowing in a distance of $200 \mathrm{~mm}$ and $400 \mathrm{~mm}$ in the horizontal section apparatus, after the gate opened from the vertical section is measured. The L - Box test givesresult on filling, passing and segregation ability of the concrete.

\subsubsection{V - Funnel Test}

Thisapparatus consists of a $\mathrm{V}$ shape funnel having a rectangular cross section. The concrete poured into the funnel with the gate blocking in the opening at the bottom. When the funnel is filled completely, the bottom gate is opened and the time for the concrete to flow out of funnel is noted. This is called "Flow Time". A flow time is less than 6 seconds is recommended for a concrete to qualify as SCC.

Table-2: Test results of fresh concrete properties of SCC with copper slag

\begin{tabular}{|l|c|c|c|c|c|c|c|c|c|c|c|}
\hline Mix Designation & $0 \%$ & $10 \%$ & $20 \%$ & $30 \%$ & $40 \%$ & $50 \%$ & $60 \%$ & $70 \%$ & $80 \%$ & $90 \%$ & $100 \%$ \\
\hline $\begin{array}{l}\text { Slump flow } \\
\text { (mm) }\end{array}$ & 665 & 673 & 675 & 682 & 682 & 682 & 681 & 679 & 672 & 664 & 663 \\
\hline $\begin{array}{l}\text { Slump flow } \\
\text { time, T50(sec) }\end{array}$ & 5 & 5 & 4 & 3 & 3 & 2 & 2 & 3 & 4 & 5 & 5 \\
\hline $\begin{array}{l}\text { V-funnel flow } \\
\text { time (Sec) }\end{array}$ & 13 & 10 & 10 & 10 & 8 & 8 & 7 & 8 & 10 & 13 & 13 \\
\hline $\begin{array}{l}\text { funnel T5min } \\
\text { (sec) }\end{array}$ & 16 & 13 & 13 & 12 & 11 & 10 & 9 & 11 & 12 & 15 & 15 \\
\hline $\begin{array}{l}\text { L-Box } \\
\text { (Blockage ratio) }\end{array}$ & 0.79 & 0.84 & 0.83 & 0.87 & 0.89 & 0.9 & 0.91 & 0.89 & 0.82 & 0.8 & 0.8 \\
\hline U-Box (mm) & 27 & 26 & 26 & 24 & 24 & 23 & 21 & 22 & 25 & 26 & 27 \\
\hline
\end{tabular}

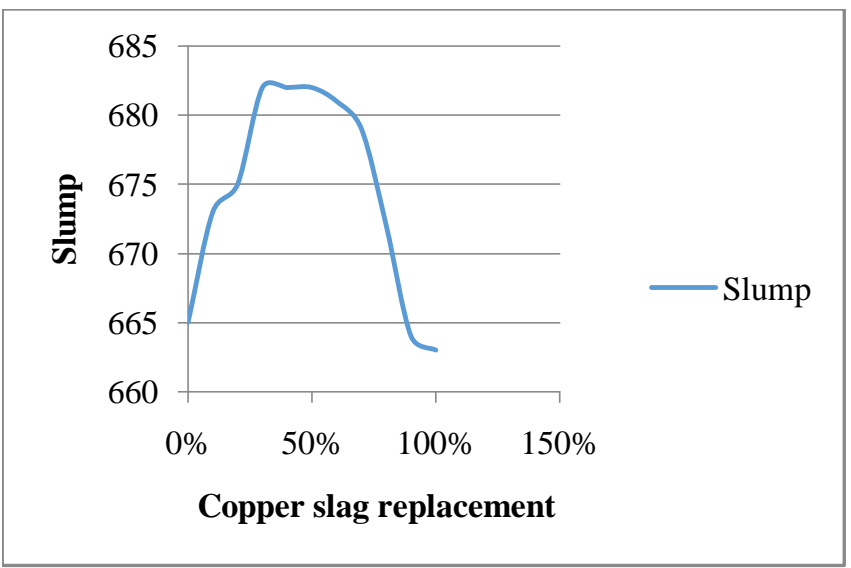

Chart -1: Variation of workability with copper slag proportions

\subsection{TESTS ON HARDENED CONCRETE}

After the necessary curing period, the concrete specimens were tested as follows. Tests like compression test and split tensile test were conducted as per IS specifications.
Table -3: Test details of hardened concrete

\begin{tabular}{|c|c|c|c|}
\hline $\begin{array}{c}\text { S. } \\
\text { No }\end{array}$ & Type of test & $\begin{array}{c}\text { Specimen } \\
\text { details }\end{array}$ & references \\
\hline 1 & $\begin{array}{c}\text { Compressive } \\
\text { strength } \\
\text { ( } 7 \text { th,and } 28 \text { th days) }\end{array}$ & $\begin{array}{c}\text { Cube - } \\
150 \times 150 \times \\
150 \mathrm{~mm}\end{array}$ & $\begin{array}{c}\text { Tests carried } \\
\text { out as per IS } \\
516-1959, \\
\text { Reaffirmed } \\
1999\end{array}$ \\
\hline 2 & $\begin{array}{c}\text { Split tensile } \\
\text { strength } \\
\left(7^{\text {th }} \text { and } 28 \text { th days }\right)\end{array}$ & $\begin{array}{c}\text { Cylinder - } \\
150 \mathrm{~mm} \\
\text { diameter } \\
\text { and } 300 \mathrm{~mm} \\
\text { height }\end{array}$ & $\begin{array}{l}\text { Tests carried } \\
\text { out as per IS } \\
5816-1999\end{array}$ \\
\hline
\end{tabular}

3. TEST RESULTS AND DISCUSSION

3.2 HARDENED CONCRETE

3.2.1 Compressive Strength 


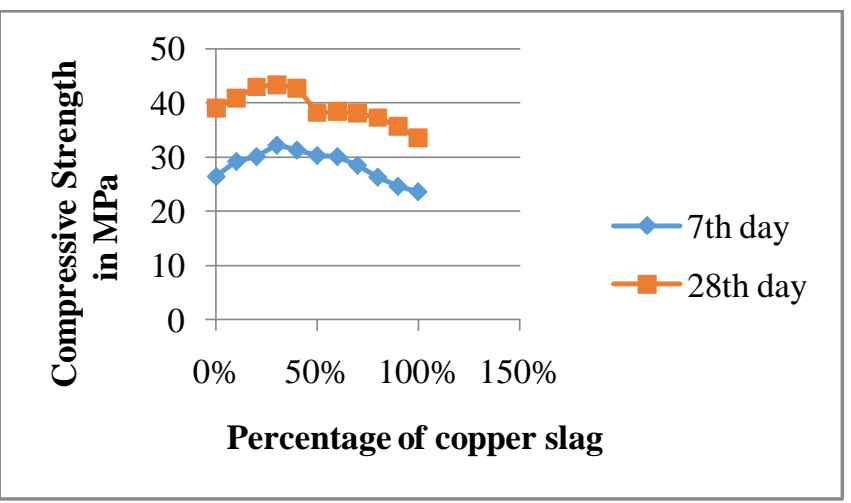

Chart -2: Variation of compressive strength for mix with copper slag proportions

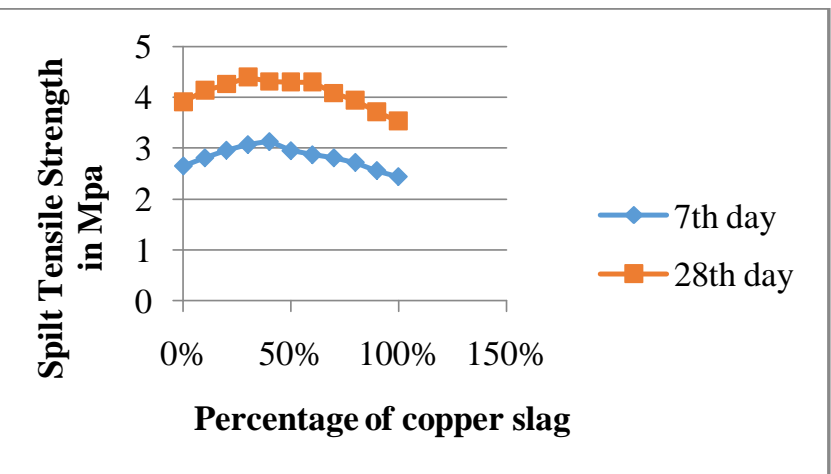

Chart -3: Variation of Spilt Tensile Strength for mix with copper slag proportions

\subsubsection{Split Tensile Strength}

Table -4: Test results of hardened concrete properties of SCC

\begin{tabular}{|l|c|c|c|c|c|c|c|c|c|c|c|}
\hline \multicolumn{1}{|c|}{ Detail } & $0 \%$ & $10 \%$ & $20 \%$ & $30 \%$ & $40 \%$ & $50 \%$ & $60 \%$ & $70 \%$ & $80 \%$ & $90 \%$ & $100 \%$ \\
\hline $\begin{array}{l}\text { Compressive } \\
\text { Strength @ 7 days } \\
\text { (MPa) }\end{array}$ & 26.4 & 29.2 & 30.1 & 32.2 & 31.3 & 30.3 & 30.1 & 28.5 & 26.3 & 24.6 & 23.6 \\
\hline $\begin{array}{l}\text { Compressive } \\
\text { Strength @ 28 days } \\
\text { (MPa)) }\end{array}$ & 39.1 & 40.9 & 43.0 & 43.4 & 42.8 & 38.2 & 38.4 & 38.1 & 37.3 & 35.7 & 33.5 \\
\hline $\begin{array}{l}\text { Split Tensile } \\
\text { Strength @ 7 days } \\
\text { (MPa) }\end{array}$ & 2.65 & 2.81 & 2.96 & 3.07 & 3.13 & 2.95 & 2.87 & 2.81 & 2.72 & 2.56 & 2.44 \\
\hline $\begin{array}{l}\text { Split Tensile } \\
\text { Strength @ 28 days } \\
\text { (MPa) }\end{array}$ & 3.91 & 4.14 & 4.26 & 4.40 & 4.31 & 4.30 & 4.30 & 4.08 & 3.94 & 3.71 & 3.53 \\
\hline
\end{tabular}

\section{CONCLUSIONS}

Evaluated the mix proportions, 3\% increase in the High performance Concrete densitywith the increase of CS content, where the workability improved more with increases in CSproportion. Accumulation of up to $40 \%$ of copper slag as fine aggregate replacement are comparable strength with that of the control mix. However, further additions of copper slag reduced its strength due to an increase of the water content in the mix content. Mixtures with 80 and 100 percentagereplacement of CS gave the less compressive strength value and the reduction in the surface water absorption as CSincrease in quantity up to 40 percentage replacement.Beyond that level of replacement, the absorption rate increases quickly and hence this paper mention that 40 percentage weight of CS can be used as replacement of river sand (fine aggregate) in order to obtain HPC with good properties.

\section{REFERENCES}

[1].Hajime Okamura and Masahiro Ouchi, (2003). SelfCompacting Concrete, Journal of Advanced Concrete Tecnology, Vol.1 No.1, 5-15.

[2].Kamal H Khayat and Joseph Assaad, (2002). Air-void Stability in Self-consolidating concrete, ACI Materials Journal, Vol.99 No.4, July-Aug 2002, 408 - 416.
[3].Ravindra Gettu, etal. (2000). Development of high strength self-compacting concrete with Flyash - A four-step experimental methodology, Universitat Politecnica de Catalunya, Spain

[4].Kamal H Khayat, Patrick Paultre and Stephan Tremblay, (2001). Structural Performance and In-place properties of Self Consolidating Concrete used for Casting Highly Reinforced Columns, ACI Materials Journal, Vol.98 No.5, $371-378$.

[5].Chao Wei Tang, Tsong Yen, Chao-shun Chang and Kuan-Hung Chen, (2001). Optimizing Mixture Properties for Flowable high-performance Concrete via Rheology Tests, ACI Materials Journal, Vol.98 No.6, 493 - 501.

[6] Khalifa S. Al-Jabri, Abdullah H. Al-Saidy, Ramzi Taha, (2011). Effect of copper slag as a fine aggregate on the properties of cement mortars and concrete - Construction and Building Materials 25 ,pp933-938.

[7] Wei Wu, Weide Zhang, Guowei, (2010). Optimum content of copper slag as a fine aggregate in high strength concrete-Materials and Design 31 ,pp 2878- 2883.

[8] N. Bouzoubaa, M. Lachemi, (2001). Self-compacting concrete incorporating high volumes of class $\mathrm{F}$ fly ash Preliminary results- Cement and Concrete Research 31 pp 413-420. 